\title{
PENGARUH TERAPI MUROTAL QUR'AN SURAH AR-RAHMAN TERHADAP PENURUNAN TEKANAN DARAH PADA PENDERITA HIPERTENSI DI WILAYAH KERJA UPT PUSKESMAS BERNUNG KABUPATEN PESAWARAN TAHUN 2020
}

\author{
1. Dwi Oktarosada 2. Nikki Annane Pangestu \\ Universitas Aisyah Pringsewu
}

Alamat: Jl. A.Yani, No 1A, Tambahrejo Kec. Gadingrejo, Kab. Pringsewu 35373,

Telp. 0729-7081587 website : www.aisyahuniversity.ac.id

e-mail : 1. dwioktarosada@gmail.com_2. nikkianane@gmail.com

\begin{abstract}
Hypertension in Indonesia is rapidly increasing with age, my physical perspective is age. In adulthood (35-45 years) has a population of 31.6\%. Murotal Qur'an therapy can reduce blood pressure by relaxing blood vessels. This study aims to determine the effect of murotal Qur'an therapy to the decrease of blood pressure in people with hypertension in the work area of UPT Puskesmas Bernung Pesawaran district in 2020. The design of this study is Quasy Experimental with pretest-prosttest design research design. The population in this study was hypertension sufferers in the Work Area of the UPT Puskesmas Bernung, Pesawaran Regency. The number of samples in this study were 10 people in the rare river village. Sampling in this study used a purposive sampling technique. Data analysis used was a time series paired $t$-test. The results of the study obtained the results ( $p$ value 0,000), meaning that there is a murotal effect of the Qur'an on the reduction of blood pressure in hypertensive patients in the Work Area of the UPT Health Center in Bernung Pesawaran District in 20020. Suggestions to UPT Bernung Puskesmas in Pesawaran Regency, murotal Qur'an therapy surah Ar-Rahman can be applied as one of the nursing interventions to help control blood pressure in people with hypertension.
\end{abstract}

\section{Keywords: hypertension, murotal Qur'an therapy, blood pressure}

\begin{abstract}
ABSTRAK
Hipertensi di Indonesia semakin pesat semakin meningkat seiring dengan peningkatan usia, prosfektif fisik saya adalah usia. Pada usia dewasa (35-45 tahun) memiliki pupulasi 31,6\%. Terapi murotal Qur'an dapat menurunkan tekanan darah dengan cara merelaksasikan pembuluh darah. Penelitian ini bertujuan mengetahui pengaruh terapi murotal Qur'an surah Ar-Rahman terhadap penurunan tekanan darah pada penderita hipertensi di Wilayah Kerja UPT Puskesmas Bernung Kabupaten Pesawaran Tahun 2020. Desain penelitian ini adalah Quasy Experimental dengan rancangan penelitian pretest-prosttest design. Populasi dalam penelitian ini adalah penderita hipertensi di Wilayah Kerja UPT Puskesmas Bernung Kabupaten pesawaran. Jumlah sampel dalam penelitian ini adalah 10 orang di desa Sungai langka. Pengambilan sampel dalam penelitian ini menggunakan tekhnik purposive sampling., Analisis data yang digunakan adalah uji t-test berpasangan time series. Hasil penelitian diperoleh hasil ( $p$ value 0,000 ), artinya ada pengaruh murotal Qur'an terhadap penurunan tekanan darah pada penderita hipertensi di Wilayah Kerja UPT Puskesmas Bernung Kabupaten pesawaran Tahun 20020. Saran kepada UPT Puskesmas Bernung Kabupaten Pesawaran, terapi murotal Qur'an surah Ar-Rahman dapat diterapkan sebagai salah satu intervensi keperawatan untuk membantu mengontrol tekanan darah pada penderita hipertensi.
\end{abstract}

Kata kunci : Hipertensi, terapi murotal Qur'an, tekanan darah 


\section{A. PENDAhUluan}

Pada masa globalisasi ini banyak masyakat yang kurang peduli dengan kesehatannya, dimulai dari yang menimbulkan penyakit tidak menular hingga yang menular. Salah satu penyakit tidak menular yang menjadi masalah kesehatanyang sangat serius saat ini adalah hipertensi. Hipertensi merupakan penyakit asimptomatik yaitu tidak menujukkan tanda dan gejala yang dapat dilihat dari luar. Penyakit hipertensi juga disebut sebagai "the silent killer" yang dapat menyebabkan kematian tanpa menunjukkan tanda dan gejala apapun (Ernawati, 2013 ; Widyastuti 2015). Hipertensi adalah keadaan peningkatan tekanan darah yang memberi gejala yang akan berlanjut ke suatu organ terget seperti stroke (untuk otak), penyakit jantung koroner (untuk pembuluh darah jantung) dan hipertropi ventrikel kanan/ left ventricle hypertrophy (untuk otot jantung). Dengan target organ di otak yang berupa stroke, hipertensi menjadi penyebab utama stroke yang membawa kematian yang tinggi (Buston, 2007 ; Ropel dan Lutfi, 2017). Komplikasi yang sering timbul akibat dari hipertensi (tekanan darah tinggi) adalah stroke, infark miokard, gagal ginjal, ensefalopati (Triyanto, 2014 ; Ropel dan Lutfi, 2017).

Berdasarkan data World Health Organization (WHO) dari $50 \%$ penderita hipertensi yang diketahui hanya $25 \%$ yang mendapat pengobatan, dan hanya $12,5 \%$ yang diobati dengan baik. Diperkirakan pada tahun 2025 nanti kasus hipertensi terutama di negara berkembang akan mengalami kenaikan sekitar $80 \%$ dari 639 juta kasus di tahun 2000, yaitu menjadi 1,15 miliyar kasus. Prediksi ini didasarkan pada angka penderita hipertensi dan pertambahan penduduk saat ini (Rahmat, 2013 dalam Ropel dan Lutfi, 2017).

Berdasarkan data dari Dinas Kesehatan Provinsi Lampung pada tahun 2012, prevelensi kejadian hipertensi dengan tekanan darah $>130 / 100 \mathrm{mmHg}$ dengan usia >30 tahun pada tahun 2010 mencapai 26.130 orang, pada tahun 2011 mencapai 26.475 orang dan pada tahun 2012 mengalami peningkatan yang signifikan hingga mencapai 27.912 orang. Dengan adanya data tersebut penyakit hipertensi menduduki peringkat ke 5 dari 10 besar penyakit yang ada di Provisi Lampung (Data Profil Dinkes Provinsi Lampung, 2012).

Penatalaksanaan klien dengan hipertensi dapat diberikan dengan terapi farmakologi dan nonfarmakologi. Terapi farmakologi yaitu terapi dengan menggunakan obat-obat antihipertensi sedangkan terapi nonfarmalogi menangani masalah tekanan darah tinggi pada pasien dapat berupa tindakan mandiri oleh perawat seperti tehnik relaksasi dan distraksi (Potter, 2005 ; Ropel dan Lutfi, 2017). Tehnik relaksasi yaitu: tehnik relaksasi nafas dalam sedangkan tehnik distraki yaitu: distraksi visual, distraksi pendengaran, distraksi pernafasan, dan imajinasi terbimbing. Salah satu tehnik distraksi yang digunakan untuk mengatasi hipertensi adalah dengan murotal (mendengarkan bacaan ayatayat Suci Al- Qur'an), karena tehnik distraksi merupakan tindakan untuk mengalihkan perhatian seperti mendengarkan murotal AlQur'an (Ropel dan Lutfi, 2017). Konsep islam mengajarkan bahwa Al-Qur'an sebagai penyembuh yang tertuang dalam QS. Al- Isra': 82.

Hasil penelitian yang dilakukan oleh (Qaidy, 1984 ; Sutrisno, 2018) tentang pengaruh Al-Qur'an bagi organ tubuh, berhasil membuktikan hanya dengan mendengarkan bacaan ayat-ayat Al-Qur'an, seorang muslim, baik mereka yang berbahasa arab maupun bukan, dapat merasakan perubahan fisiologis yang sangat besar.

Murotal adalah salah satu musik yang memiliki pengaruh positif bagi pendengarnya (Zahrofi, 2013). Terapi murotal dapat mempercepat penyembuhan, hal ini telah dibuktikan oleh berbagai ahli seperti yang telah dilakukan Ahmad Al- Khadi direktur umum Islamic Medicine Institute for Education and Research di Florida, Amerika Serikat. Dalam konferensi tahunan ke XVII Ikatan Dokter Amerika, dengan hasil penelitian bahwa mendengarkan ayat suci Al-Qur'an memiliki pengaruh yang signifikan dalam menurunkan ketegangan saraf relaktif dan hasil ini tercatat dan terukur secara kuantitatif dan kualitatif oleh alat berbasis computer. Dari hasil penelitian tersebut menunjukan $97 \%$, bahwa mendengarkan ayat

suci Al-Qur'an memiliki pengaruh mendatangkan ketenanngan dan menurunkan ketegangan urat syaraf relektif (Remolda, 2009 ; Aini, 2017).

Murotal adalah rekaman suara Al- Qur'an yang dilagukan oleh seorang qori' (pembaca Alqur'an) (Purna, 2006 ; Ropel dan Lutfi, 2017). Lantunan Al-Qur'an secara fisik mengandung unsur suara manusia, sedangkan suara manusia merupakan instrumen penyembuhan yang menakjubkan dan alat yang paling mudah dijangkau. Suara dapat menurunkan hormonhormon stres, mengaktifkan hormon endorfin alami, meningkatkan perasaan rileks, dan mengalihkan perhatian dari rasa takut, cemas dan tegang, memperbaiki sistem kimia tubuh sehingga menurunkan tekanan darah serta memperlambat pernafasan, detak jantung, denyut nadi dan aktivitas gelombang otak (Heru, 2008 ; Ropel dan Lutfi, 2017).

Ar-Rahman sendiri adalah Nama Allah yang berarti "Maha Pemberi nikmat dunia dan akhirat". Begitu Rahmatnya Allah samapai Allah mengkhususkan Ar-Rahman dalam satu surat yang indah. Pengingat untuk manusia akan banyaknya nikmat Allah yang terlupa (Remolda, 
2009 : Sutrisno, 2018). Tema dalam surah ini adalah uraian tentang nikmat Allah yang bermula dari nikmt terbesar yaitu Al-Qur'an. Thabathaba'i berpendapat bahwa surah ini mengandung isyarat tentang ciptaan Allah dengan sekian banyak bgaian-bagiannya di langit dan di bumi, darat dan laut, manusia dan jin, dimana Allah mengatur semua itu dalam satu pengaturan yang bermanfaat bagi manusia dan jin. Bermanfaat pula untuk hidup mereka di dunia maupun akhirat (Remolda, 2009 ; Sutrisno, 2018).

Terapi musik dan terapi murotal ini bekerja pada otak, dimana ketika didorong oleh rangsangan dari luar (terapi musik dan Al-Qur'an), maka otak akan memproduksi zat kimia yang disebut neuropeptide. Molekul ini akan menyangkutkan ke dalam reseptor- reseptor mereka yang ada di dalam tubuh dan akan memberikan umpan balik (Aini, 2017). Adapun pengaruh terapi pembacaan Al- Quran berupa adanya perubahan-perubahan arus listrik di otot, perubahan sirkulasi darah, perubahan detak jantung, dan kadar darah pada kulit. Perubahan tersebut menunjukkan adanya relaksasi atau penurunan ketegangan urat saraf reflektif yang mengakibatkan terjadinya pelonggaran pembuluh nadi dan penambahan kadar darah dalam kulit, diiringi dengan penurunan frekuensi detak jantung. (Aini, 2017). Menurut Anwar (2010) dalam Erlina dan Raharjo (2016) murottal Al- Qur'an akan memberikan efek ketenangan dalam tubuh sebab adanya unsur meditasi, autosugesti dan relaksasi yang terkandung didalamnya. Rasa tenang ini kemudian akan memberikan respon emosi positif yang sangat berpengaruh dalam mendatangkan persepsi positif. Temuan fakta ini semakin membuktikan bahwa terapi bacaan Al-quran akan memberikan

ketenangan dan relaksasi bagi yang mendengarkan (Alkahel, 2011), yang berefek menurunkan tekanan darah.

Menurut Mustamir (2009) dalam Erlina dan Raharjo (2016) persepsi positif yang didapat dari murottal Ar-Rahman selanjutnya akan merangsang hipotalamus untuk mengeluarkan hormon endorfin, seperti yang kita tau hormon ini akan membuat seseorang merasa bahagia. Selanjutnya amigdala akan merangsang pengaktifan sekaligus pengendalian saraf otonom yang terdiri dari saraf simpatis dan parasimpatis. Rangsangan saraf otonom yang terkendali akan menyebabkan sekresi epinefrin dan norepinefrin oleh medula adrenal menjadi terkendali pula. Terkendalinya hormon epinefrin dan norepinefrin akan menghambat pembentukan angiotensin yang selanjutnya dapat menurunkan tekanan darah.

Berdasarkan hasil penelitian yang dilakukan Mulyadi (2016) tentang terapi murottal terhadap perubahan tekanan darah pada lansia penderita hipertensi di panti sosial rehabilitasi lanjut usia mulia dharma kabupaten kubu raya. Dalam penelitiannya, menyatakan bahwa terjadi perubahan tekanan darah yang bermakna antara sebelum dan sesudah diberikan terapi murottal Qur'an kepada lanjut usia penderita hipertensi, yang mana terjadi perubahan tekanan darah sistolik pre dan post.

Menurut data kunjungan pasien di UPT

Puskesmas Bernung Kabupaten Pesawaran sepanjang tahun 2014-2018 diperoleh data bahwa jumah kunjungan pasien dengan diagnosa hipertensi adalah 1401 orang menduduki peringkat ke 3 (tiga) dari sepuluh besar penyakit di UPT Puskesmas Bernung Kabupaten Pesawaran. (Profil Puskesmas Bernung Tahun 2018). Apabila dapat dilakukan di Puskesmas

Bernung untuk menangani kasus-kasus hipertensi yang cukup banyak bahwasannya peneliti ingin mencoba dengan terapi yang baru atau dengan terapi murotal Qur'an. Fenomena di atas melatar belakangi untuk dilakukannya penelitian ini.

\section{B. TUJUAN}

1. Tujuan umum

Mengetahui pengaruh terapi murotal Qur'an surah Ar- Rahman terhadap penurunan tekanan darah pada penderita hipertensi.

2. Tujuan khusus

a. Untuk mengetahahui distribusi frekuensi tekanan darah sistolik dan diastolik pada penderita hipertensi sebelum dilakukan terapi murotal Qur'an,

b. Untuk mengetahui distribusi frekuensi tekanan darah sistolik dan diastolik pada penderita hipertensi setelah dilakukan terapi murotal Qur'an,

c. Untuk mengetahui pengaruh terapi murotal Qur'an terhadap tekanan darah sistolik dan diastolik pada penderita hipertensi.

\section{METODE}

Metode penelitian dalam penelitian ini menggunakan metode kuantitatif, jenis penelitian yang dipakai menggunakan Quasy Experimental, dengan rancangan penelitian one group pretest-prosttest design. Desain ini dilakukan dengan cara memberikan pretest atau pengamatan awal telebih dahulu sebelum diberikan intervensi, setelah itu diberikan intervensi, kemudian dilakukan posttest atau pengamatan akhir (Notoatmodjo, 2018). Penelitian dilakukan di wilayah kerja UPT Puskesmas Bernung Kabupaten Pesawaran pada tanggal 11-17 Febuari tahun 2020.

Pada penelitian ini dilakukan dengan cara mengukur tekanan darah terlebih dahulu 5 menit kemudian diberikan intervensi setelah dilakukan intervensi 5 menit kemudian dilakukan pengukuran ulang (post test) dan dilakukan 
selama 7 kali.

Tabel 1

Pretest-Posttest Design

Pre Intervensi Perlakuan Post Intervensi

\begin{tabular}{|c|c|c|}
\hline 01 & $\mathrm{X}$ & 02 \\
\hline
\end{tabular}

Keterangan :

$\mathrm{X}$ : Intervensi (terapi murotal Qur'an surah Ar-Rahman)

01 : Pengukuran tekanan darah sebelum intervensi

02 : Pengukuran tekanan darah sesudah terapi

Populasi dalam penelitian ini adalah penderita hipertensi di Desa Sungai Langka Kecamatan Gedong Tataan Kapubaten Pesawaran sebanyak 1401 orang. Tehnik pengambilan sampel menggunakan Purposive sampling yaitu sampel didapat dengan pertimbangan tertentu yang dibuat oleh peneliti sendiri, berdasarkan ciri atau sifatsifat populasi yang sudah diketahui sebelumnya (Notoatmojo, 2018). Kriteria inklusi:

1. Bersedia menjadi responden,

2. Isi pembicaraan dapat dipahami dengan jelas,

3. Laki-laki dan perempuan,

4. Beragama islam,

5. Usia dewasa tua (36-45 tahun),

6. Tidak mengalami gangguan pendengaran,

7. Hipertensi primer dengan tekanan darah sistolik $\geq 140 \mathrm{mmHg}$ dan tekanan darah diastolik $\geq 90 \mathrm{mmHg}$.

Instrumen penelitian yang digunakan yaitu handphone, earphone, tensimeter digital, lembar observasi pengukuran tekanan darah dan menggunakan murotal surah Ar-Rahman (1-78) dengan qori Mishari Rasyid. Hasil penelitian dianalisa dengan cara univariat dan bivariat.

\section{HASIL DAN PEMBAHASAN}

$$
\text { Bab ini } \begin{gathered}
\text { menguraikan hasil } \\
\text { penelitian }
\end{gathered}
$$

beserta pembahasannya yang meliputi penjabaran umum dan khusus serta analisis mengenai perubahan tekanan darah pada penderita hipertensi sebelum dan sesudah dilakukan terapi murotal Qur'an surah Arrahman di wilayah kerja UPT Puskesmas Bernung Kabupaten Pesawaran.

\section{Karakteristik Responden}

Tabel 2.

Distribusi Frekuensi Karakteristik Responden $\mathrm{n}=10$

\begin{tabular}{|l|c|c|}
\hline \multicolumn{2}{|c}{ Responden $\mathrm{n}=10$} \\
\hline Variabel & Jumlah & $\begin{array}{c}\text { Presentase } \\
(\boldsymbol{\%})\end{array}$ \\
Kenis & 5 & 50 \\
Laki-Laki & 5 & 50 \\
Perempuan & & \\
\hline Umur: & & 30 \\
$35-40$ & 3 & 70 \\
$41-45$ & 7 & 40 \\
\hline Riwayat & & 60 \\
Hipertensi: & 4 & \\
$<10$ tahun & 6 & \\
$>10$ tahun & & \\
\hline
\end{tabular}

Berdasarkan tabel 2, dapat diketahui bahwa responden berjenis kelamin laki-laki sebanyak 5 orang $(50 \%)$ dan responden perempuan sebanyak 5 orang $(50 \%)$, responden berdasarkan umur sebanyak 7 orang (70\%) pada umur 41-45 tahun adalah dengan presentase terbanyak, sedangkan pada umur 35-40 tahun sebanyak 3 orang (30\%), dan responden berdasarkan riwayat hipertensi sebanyak 6 orang (60\%) yang menderita hipertensi $>10$ tahun, sedangkan yang menderita hipertensi $<10$ tahun sebanyak 4 orang (40\%).

\section{Analisis Univariat}

Tabel 3

Distribusi frekuensi rata-rata tekanan darah sebelum dilakukan terapi murotal Qur'an di wilayah kerja UPT Puskesmas Bernung Tahun 2020

\begin{tabular}{|c|c|c|l|c|}
\hline Group & Mean & SD & Min & Max \\
\hline $\begin{array}{c}\text { Presistole } \\
(\mathrm{n}=10)\end{array}$ & 185.30 & 20.440 & 162 & 299 \\
\hline $\begin{array}{c}\text { Prediastole } \\
(\mathrm{n}=10)\end{array}$ & 105.60 & 16.655 & 83 & 135 \\
\hline
\end{tabular}

Berdasarkan tabel 3 diperoleh bahwa rata-rata tekanan darah responden sebelum diberikan terapi murotal Qur'an surah Ar- Rahman yaitu $185.30 \mathrm{mmHg}$ sistol dan 105,60 $\mathrm{mmHg}$ diastol. Hasil penelitian ini sejalan dengan penelitian yang dilakukan oleh Suiraoka (2012) yang menjadi standar dalam menentukan hipertensi adalah diastolik. 
Tabel 4

Distribusi frekuensi rata-rata tekanan darah sesudah dilakukan terapi murotal Qur'an di wilayah kerja UPT Puskesmas Bernung Tahun 2020

\begin{tabular}{|c|r|r|r|c|}
\hline Group & Mean & SD & Min & Max \\
\hline $\begin{array}{c}\text { Postsistole } \\
(\mathrm{n}=10)\end{array}$ & 156.10 & 24.465 & 118 & 196 \\
\hline $\begin{array}{c}\text { Postdiastole } \\
(\mathrm{n}=10)\end{array}$ & 87.60 & 9.513 & 74 & 102 \\
\hline
\end{tabular}

Berdasarkan tabel 4, diperoleh bahwa ratarata tekanan darah responden setelah diberikan terapi murotal Qur'an yaitu 156,10 $\mathrm{mmHg}$ sistol dan $87,60 \mathrm{mmHg}$ diastol. Hasil penelitian ini sejalan dengan penelitian yang dilakukan oleh Widyastuti (2015) pada pengaruh terapi murotal surah Ar-Rahman terhadap perubahan tekanan darah pada lanjut usia penderita hipertensi di Posyandu lansia kenanga wilayah kerja UPK Puskesmas Siantan Hulu Kecamatan Pontianak Utara, yang dilakukan pada 24 responden didapatkan nilai tekanan darah sistolik dan diastolik sesudah diberikan terapi murotal surah Ar-Rahman masing- masing memilki nilai ratarata yaitu 139,42 mmHg/ $85 \mathrm{mmHg}$. Nilai tekanan darah sistolik dan diastolik sebelum diberikan terapi surah Ar-Rahman masingmasing memilki nilai rata-rata yaitu 151,88 $\mathrm{mmHg} / 90 \mathrm{mmHg}$.

Hal ini juga sesuai dengan teori yang dikemukakan oleh Mustamir, (2009) persepsi positif yang didapat dari murottal Ar Rahman selanjutnya akan merangsang hipotalamus untuk mengeluarkan hormon endorfin, seperti yang kita tau hormon ini akan membuat seseorang merasa bahagia.

\section{Analisis Bivariat}

Analisa bivariat dalam penelitian ini mengunakan uji $\mathrm{T}$ independen (independent sample T-Test) untuk itu perlu dilakukan uji prasyarat antara lain uji normalitas. Hasil uji normalitas data disajikan pada tabel 5.

Tabel 5

Uji normalitas data

\begin{tabular}{|l|c|c|r|}
\hline \multicolumn{1}{|c|}{ Variabel } & Statistic & Df & Sig. \\
\hline PRESISTOLE & 913 & 10 & 303 \\
\hline POSTSISTOLE & 964 & 10 & 827 \\
\hline PREDIASTOLE & 897 & 10 & 204 \\
\hline POSTDIASTOLE & 924 & 10 & 392 \\
\hline
\end{tabular}

Tabel 6

Pengaruh terapi murotal Qur'an terhadap penurunan teknan darah sistolik pada penderita hipertensi

\begin{tabular}{lllcc}
\hline Variabel & Group & Mean & SD & $p$ Value \\
\hline Tekanan & Sistolik & & & \\
darah & Sebelum & 29.2000 & 10.685 & .000 \\
& $\begin{array}{l}\text { Sesudah } \\
\text { Perbedaan }\end{array}$ & & & \\
& $\begin{array}{l}\text { Rata-rata } \\
\text { Rata }\end{array}$ & & & \\
\hline
\end{tabular}

Tabel 7

Pengaruh terapi murotal Qur'an terhadap penurunan teknan darah diastolik pada penderita hipertensi

\begin{tabular}{lllll}
\hline Variabel & Group & Mean & SD & $p$ Value \\
\hline Tekanan & Sistolik & & & \\
darah & Sebelum & 18.000 & 10.306 & .000 \\
& $\begin{array}{l}\text { Sesudah } \\
\text { Perbedaan } \\
\end{array}$ & & & \\
& Rata-rata & & & \\
\hline
\end{tabular}

Berdasarkan hasil penelitian pada tabel 6 dan tabel 7 diperoleh bahwa ada pengaruh Terapi murotal Qur'an surah Ar-Rahman terhadap penurunan tekanan darah pada penderita hipertensi di wilayah kerja UPT Puskesmas Bernung Kabupaten Pesawaran Tahun 2019 ((p-value $=0,000$ (sistol) dan $p$ value $=0,000$ (diastol)) yang berarti Ho ditolak.

Hal ini sesuai dengan penelitian yang dilakukan oleh Widyastuti (2015) tentang pengaruh terapi murottal surah Ar-Rahman terhadap perubahan tekanan darah pada lanjut usia (lansia) penderita hipertensi di Posyandu Lansia Kenanga wilayah kerja UPK Puskesmas Siantan Hulu Kecamatan Pontianak Utara. Uji statistik dengan uji $\mathrm{T}$ berpasangan didapatkan bahwa nilai $p$ tekanan darah sistolik sebelum dan setelah diberikan terapi murottal surah $A r$ Rahman adalah 0.000 dan hasil uji Wilcoxon didapatkan bahwa nilai $p$ tekanan darah diastolik sebelum dan setelah dilakukan terapi murottal surah Ar-Rahman adalah 0.000. Hasil tersebut menunjukkan bahwa nilai $p$ tekanan darah sistolik dan diastolik lebih kecil dari 0.05.

Hal ini sesuai dengan teori yang dikemukakan oleh Anwar, (2010) murottal Al-Qur'an akan memberikan efek ketenangan dalam tubuh sebab adanya unsur meditasi, autosugesti dan relaksasi yang terkandung didalamnya. Rasa tenang ini kemudian akan memberikan respon emosi positif yang sangat berpengaruh dalam mendatangkan persepsi positif. Temuan fakta ini semakin membuktikan bahwa terapi bacaan Al-quran akan memberikan

ketenangan dan relaksasi bagi yang mendengarkan (Alkahel, 2011), yang berefek menurunkan tekanan darah

Menurut pendapat peneliti menyimpulkan bahwa terapi murottal surah Ar-Rahman ini efektif untuk menurunkan tekanan darah pada penderita hipertensi. Peneliti juga sependapat bahwa lantunan suara Al-Qur'an (Murottal) 
mempunyai manfaat yang dapat berpengaruh terhadap kesehatan, karena mengandung unsur meditasi, autosugesti dan relaksasi. Terapi murottal ini juga merupakan terapi tanpa efek samping yang aman dan mudah sehingga dapat dilakukan secara rutin oleh penderita hipertensi sebagai terapi mandiri di rumah.

Tabel 8

Perbandingan rata-rata tekanan darah sistolik dan diastolic sesudah diberikan terapi murotal Qur'an

\begin{tabular}{lcccc}
\hline Group & $\mathrm{T}$ & Df & $\begin{array}{c}\text { Mean } \\
\text { difference }\end{array}$ & $\begin{array}{c}\text { Sig.(2- } \\
\text { tailed) }\end{array}$ \\
\hline $\begin{array}{l}\text { Equal } \\
\text { vainances } \\
\text { assumed }\end{array}$ & 8.252 & 18 & 68500 & 000 \\
$\begin{array}{l}\text { Equal } \\
\text { variances } \\
\text { pot } \\
\text { assimed }\end{array}$ & 8.252 & 11.660 & 68500 & 000 \\
\hline
\end{tabular}

Berdasarkan tabel 8 , terlihat bahwa nilai mean difference $68.500 \mathrm{mmHg}$ setelah diberikan terapi murotal Qur'an. Hasil penelitian ini juga sejalan dengan penelitian yang dilakukan oleh Annisa (2017) hasil uji statistic yang digunakan adalah Uji Wilcoxon Signed Ranks Test dan Uji MannWhitney. Hasil Uji Wilcoxon Test berpasangan menunjukan terdapat penurunan tekanan darah sistol yang bermakna pada kelompok intervensi pada kelompok kontrol tidak terjadi penurunan tekanan darah sistol. Uji

Mann-Whitney menunjukan bahwa mendengarkan dan membaca Al-Qur'an memiliki pengaruh yang bermakna terhadap penurunan tekanan darah sistol. Terdapat perbedaan hasil penurunan tekanan darah pada 10 responden yang sangat signifikan yang antara lain dipengaruhi oleh beberapa faktor seperti genetik, umur, kekurangan olahraga serta nutrisi.

\section{E. PENUTUP}

\section{Kesimpulan}

Kesimpulan yang dapat diambil dari penelitin ini adalah sebagai berikut:

a. Distribusi frekuensi rata-rata tekanan darah responden sebelum dilakukan terapi murotal Qur'an surah Ar-Rahman yaitu, sistolik 185,30 $\mathrm{mmHg}$ dan diastolik 105,60 $\mathrm{mmHg}$.

b. Distribusi frekuensi rata -rata tekanan darah responden setelah dilakukan terapi murotal Qur'an surah Ar-Rahman yaitu, sistolik $156,10 \mathrm{mmHg}$ dan diastolik 87,60 $\mathrm{mmHg}$.

c. Ada pengaruh terapi murotal Qur'an terhadap penurunan tekanan darah pada penderita hipertensi di Wilayah Kerja UPT Puskesmas Bernung Kabupaten Pesawaran Tahun 2020 dengan $\mathrm{P}$ value $=0,000$

\section{Saran}

Adapun saran yang dapat diberikan peneliti untuk penelitian berikutnya adalah:

a. Bagi UPT Puskesmas Bernung Diharapkan petugas kesehatan di wilayah kerja Puskesmas Beenung untuk dapat memberikan informasi kepada pasien atau keluarga khususnya tentang terapi murotal Qur'an pada penderita hipertensi untuk membantu mengontrol tekanan darah.

b. Bagi peneliti

Peneliti selanjutnya diharapkan dapat melakukan penelitian yang lebih mendalam dengan menambah jumlah sampelnya, dan menambahkan variabel lain yang berhubungan dengan terapi murotal Qur'an,

c. Bagi pendidikan

Diharapkan hasil penelitian ini dapat dijadikan referensi, bahan masukan dan pengyaan ilmu keperawatan khususnya mahasiswa keperawatan.

\section{Daftar Pustaka}

-. (2013). Al-Qur'an dan Terjemahan. Bandung: CV Penerbit Diponegoro

(2012).Waspadaihipertensikendalikante kanandarah,http://pppl.depkes.go.id. Diunduh pada tanggal 1 november 2018

.(2014). nfodatinHipertensi, Jakarta: Kementrian Kesehatan RI. Diunduh pada tanggal 19 november 2019.

.(2013). RisetKesehatanDasar (RISKESDAS). Jakarta: Kementrian Kesehatan RI. Diunduh pada tanggal 19 november 2019.

Amar, Y. (2016). Badan sehat ibadah jadi hebat. Depok: Gema Insani

Annisa, T. (2017). Pengaruh mendengarkan dan membaca Al-Qur'an terhadap penurunan tekanan darah pada lansia di panti sosial tresna werdha mabaji gowa. Skripsi. Diunduh pada tanggal 31 oktober 2017 dari

http://repositiri.uimalauddin.ac.id/4144/ 1/thahirah\%20annisa

Aini, D. N. \& Astuti, S. P. (2017). Pengaruh terapi murottal Al-Qur'an terhadap tekanan darah pada pasien hipertensi di ruang cempaka rsud dr. h. soewondo kendal. Jurnal Ners. Diunduh pada 
tanggal 16 oktober 2019 dari http://stikeswh.ac.id:8082/journal/index. php/jners/article/viewFile/177/168

Bustan, M. N. (2017). Epidemiologi penyakit tidak menular. Jakarta: PT Rineka Cipta

Casey, A. \& Benson, H. (2016). Menurunkan tekanan darah. Jakarta: PT Bhuana Ilmu Populer

Erlina. \& Raharjo, S. B. (2016). Terapi murottal surat Ar-Rahman terhadap perubahan tekanan darah pasien hipertensi di rsudza banda aceh .Jurnal ilmiah mahasiswa fakultas keperawatan. Diunduh pada tanggal 16 oktober 2019 dari http://jim.unsyiah.ac.id/FKep/article/view/1 $\underline{672}$

Fikri I. M. (2013). Pengaruh membaca Al- Qu'an terhadap tekanan darah pada lansia hipertensi di wilayah kerja puskesmas ciputat. Sripsi. Diunduh pada tanggal 31 oktober 2017 dari http://respiratory.uinjkt.ac.id/dspace/bitstrea $\mathrm{m} / 123456789 / 25551 / 1 /$ Imam\%20Maulana\% 20Fikri\%20-\%20fkik.pdf

Kaheel, A. (2015). Obati dirimu dengan AlQur'an. Tanggerang: Iniperbesa

Marlina,S. \& Tantan. (2017). 100 question \& answer hipertensi.. Jakarta: PT Gramedia

Mtaqin, A. (2011). Pengantar asuhan keperawatan klien dengan gangguan sitem kardiovaskuler. Jakarta: Salembamedika

Notoatmodjo, S. (2018).Metodologi penelitian kesehatan. Jakarta: RinekaCipta

Riyadi, S. (2011).Keperawatan medical bedah.. Yogyakarta: Pustaka Belajar

Ropel, O. \& Luthfi, M. (2017). Pengaruh terapi psikoreligi murottal Al-Qur-an terhadap tekanan darah pada klien dengan hipertensi. Jurnal keperawatan aisyah. Diunduh pada tanggal 31 okto ber 2017 dari http://jurnalkeperawatan.stikesaisyahbandun g.ac.id/file/JKA_V04_N01_06

2017(art01).pdf

Udjiyanti, W.J. (2013). Keperawatan kardiovaskuler.Jakarta: Selemba Medika

Widyaastuti, I.W.(2015). Pengaruh terapi murottal surah ar-rahman terhadap perubahan tekanan darah pada lanjut usia (lansia) penderita hipertensi di posyandu lansia kenanga wilayah kerja upk puskesmas siantan hulu kecamatan Pontianak utara. Naskah Publikasi. Diunduh pada tanggal 31 poktober 2017 dari http://jurnal.untan.ac.id/index.php/jmkepera watanFK/article/download/11/12/10491 
